\title{
Global distributions of nitric acid from IASI/MetOP measurements
}

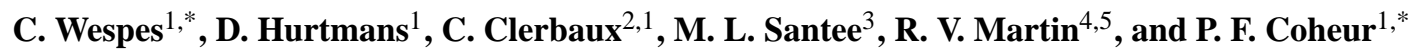 \\ ${ }^{1}$ Spectroscopie de l'Atmosphère, Chimie Quantique et Photophysique, Université Libre de Bruxelles (U.L.B.), \\ Brussels, Belgium \\ ${ }^{2}$ UPMC Univ. Paris 06; Université Versailles St.-Quentin, CNRS/INSU, LATMOS-IPSL, Paris, France \\ ${ }^{3}$ Jet Propulsion Laboratory, California Institute of Technology, Pasadena, California, USA \\ ${ }^{4}$ Department of Physics and Atmospheric Science, Dalhousie University Halifax, Canada \\ ${ }^{5}$ Harvard-Smithsonian Center for Astrophysics, Cambridge, Massachusetts, USA \\ *FRIA Researcher and Research Associate with the FRS-FNRS, Belgium
}

Received: 29 January 2009 - Published in Atmos. Chem. Phys. Discuss.: 25 March 2009

Revised: 7 August 2009 - Accepted: 29 September 2009 - Published: 22 October 2009

\begin{abstract}
This paper presents the first global distributions of $\mathrm{HNO}_{3}$ total columns acquired by the Infrared Atmospheric Sounding Interferometer (IASI) instrument, launched onboard the MetOp platform in October 2006. IASI is an infrared nadir-looking Fourier transform spectrometer providing atmospheric radiance spectra at $0.5 \mathrm{~cm}^{-1}$ spectral resolution, from which temperature and infrared absorbing gas concentration profiles are retrieved with global Earth coverage twice a day. A first analysis of the IASI measurements in terms of information content demonstrates the possibility of retrieving a total column for $\mathrm{HNO}_{3}$ at all latitudes with a maximal sensitivity in the middle stratosphere. The retrievals are performed from IASI spectra in the atmospheric window using a fast radiative transfer model and inversion software (FORLI) relying on the Optimal Estimation Method. The operational processing of $\mathrm{HNO}_{3}$ total columns is achieved since March 2008. We show that FORLI-HNO $\mathrm{H}_{3}$ performs well at all latitudes (RMS of the spectral residuals around $2.3 \times 10^{-6} \mathrm{~W} / \mathrm{m}^{2} \mathrm{sr} \mathrm{m}^{-1}$ ) and provides $\mathrm{HNO}_{3}$ total columns with on average statistical errors of about $12 \%$, reaching the threshold value of $32 \%$ at the equatorial belt. The global distributions of the retrieved total columns for one year (from March 2008 to February 2009) are presented and discussed with emphasis given to seasonal and interhemispheric variations. Local seasonal variations at 6 specific locations are also described and discussed in comparison with MLS volume mixing ratios at $46.5 \mathrm{hPa}$. The seasonal cycle observed
\end{abstract}

\section{Correspondence to: C. Wespes} (cwespes@ulb.ac.be) in Polar regions is highlighted, with maxima observed in fallwinter and minima during spring-summer. The denitrification inside the Antarctic polar vortex during winter is clearly revealed with unprecedented horizontal resolution: $\mathrm{HNO}_{3}$ columns decreasing down to about $1 \times 10^{16}$ molecules $\mathrm{cm}^{-2}$ are observed, which is consistent with the lower values of temperature observed between 50 and $15 \mathrm{hPa}(\sim 20-25 \mathrm{~km})$ and the resulting formation and sedimentation of polar stratospheric clouds. During the same period, the collar region of high quantities of $\mathrm{HNO}_{3}$ at the vortex edge is also observed around $65-60^{\circ} \mathrm{S}$ latitude. Preliminary correlations between IASI derived $\mathrm{HNO}_{3}$ and $\mathrm{O}_{3}$ columns inside the polar vortex are presented and discussed.

\section{Introduction}

$\mathrm{HNO}_{3}$ is the dominant form of oxidized nitrogen in the atmosphere, usually abbreviated as $\mathrm{NO}_{\mathrm{y}}\left(\mathrm{NO}_{\mathrm{y}}=\mathrm{NO}_{\mathrm{x}}\right.$ toxidized products, with $\mathrm{NO}_{\mathrm{x}}=\mathrm{NO}+\mathrm{NO}_{2}$ ). It is an important reservoir and sink species for $\mathrm{NO}_{\mathrm{x}}$ in both the troposphere and the stratosphere and as such is a key component for the understanding of the chemical processes in the lower atmosphere (Solomon, 1999; Brasseur and Solomon, 2005). Deposition of $\mathrm{HNO}_{3}$ at the surface in the form of acid rain is a threat for the environment and contributes to the acidification of soils and water. Nitric acid is mainly present in the stratosphere at polar latitudes where only a small fraction (about $10-15 \%$ on a column basis) is in the troposphere. In the stratosphere, it contributes, along with other oxidized forms, in sequestering $\mathrm{NO}_{\mathrm{x}}$, thereby reducing catalytic ozone destruction processes

Published by Copernicus Publications on behalf of the European Geosciences Union. 
(Solomon, 1999; Brasseur and Solomon, 2005). It is removed from this layer either by photochemistry or by sedimentation of Polar Stratospheric Cloud (PSC) particles containing $\mathrm{HNO}_{3}$ during the cold polar nights. This process causing stratospheric denitrification also influences chlorine chemistry and is an important factor governing the ozone hole development in polar springtime (Solomon, 1999; Santee et al., 1999, 2004; Jin et al., 2006, and references therein).

In the troposphere, $\mathrm{HNO}_{3}$ is the dominant sink of $\mathrm{NO}_{\mathrm{x}}$. Its role as a reservoir species involved in long-range transport of $\mathrm{NO}_{\mathrm{x}}$ pollution is, however, not excluded (Hauglustaine et al., 1998; Emmons et al., 2000; Bey et al., 2001; Neuman et al., 2006). Nitrate aerosols formed from $\mathrm{HNO}_{3}$ in the troposphere are also of increasing importance for climate (Adams et al., 2001).

Until recently, $\mathrm{HNO}_{3}$ observations were restricted to local measurements in the troposphere, for example during airborne campaigns (Emmons et al., 2000 and references therein; Miyazaki et al., 2003; Hudman et al., 2004), or to extensive satellite measurements in the stratosphere and in the upper troposphere. Global distributions of $\mathrm{HNO}_{3}$ in the stratosphere have been obtained from a series of limbsounders operating in the infrared (IR) or millimeter spectral range by averaging over time. These have highlighted spatial, seasonal and inter-annual variations (Koike et al., 2000; Irie et al., 2002, 2006; Santee et al., 1999, 2004, 2005, 2007; Urban et al., 2005; Tsidu et al., 2005; Stiller et al., 2005; Wang et al., 2007; Fischer et al., 2008; Orsolini et al., 2008; von Clarmann et al., 2009). The longest and the most complete set of observations was recorded between 1991 and 1998 by the Microwave Limb Sounder (MLS) on board the Upper Atmosphere Research Satellite (UARS). These long term observations in the stratosphere are complemented by the Odin Sub-Millimetre Radiometer (SMR) since 2001, by MLS on the Aura satellite since 2004 (Santee et al., 2004, 2007 and Urban et al., 2008), by the Michelson Interferometer for Passive Atmospheric Sounding (MIPAS) on Envisat platform (Tsidu et al., 2005; Stiller et al., 2005; Fisher et al., 2006; Wang et al., 2007) and the Atmospheric Chemistry Experiment Fourier Transform Spectrometer (ACE-FTS) infrared instrument (Bernath et al., 2005; Martin et al., 2006; Wolff et al., 2008). In the best cases, these limb-sounders enable sounding down to the upper troposphere but are limited for measuring $\mathrm{NO}_{\mathrm{x}}$ pollution sources outflow and chemical transformation.

High resolution nadir infrared satellite measurements have very recently demonstrated their capability to assess global distributions of nitric acid partial columns in the troposphere and the stratosphere with a limited sensitivity to the vertical profiles (Wespes et al., 2007). These promising results were obtained by analyses of the Interferometric Monitor for Greenhouse gases instrument (IMG)/ADEOS, which provided measurements for 10 months in 1996-1997. It is the only global scale distribution available up to now. From the Tropospheric Emission Spectrometer (TES)/Aura
(Beer et al., 2006) and from the Atmospheric Infrared Sounder (AIRS) on Aqua, even if measurements of $\mathrm{HNO}_{3}$ are achieved, to the best of our knowledge, operational products and geophysical studies of the resulting fields have not been performed.

The Infrared Atmospheric Sounding Interferometer (IASI) satellite launched onboard the MetOp platform is a relatively high spectral resolution IR sounder, covering an extended spectral range with a very low radiometric noise. Owing to its spatial and temporal coverage, the IASI mission is providing global measurements of accurate temperature and atmospheric abundances for about 10 species twice a day, with small ground pixel size (Clerbaux et al., 2009). As MetOp is an operational satellite, near real time global distributions of $\mathrm{HNO}_{3}$ can be measured and column measurements from IASI have been performed at the "Université Libre de Bruxelles" (ULB) since March 2008 using a dedicated fast radiative transfer model.

This paper shows the first results of 12 months of IASI processing, focusing on global distributions and seasonal variations. The total columns are dominated by the stratosphere, and the geophysical analysis is therefore oriented towards stratospheric chemistry, in particular over polar regions. In Sect. 2, the characteristics of IASI measurements and the retrieval method are described. In Sect. 3, we briefly discuss the vertical sensitivity and errors of the measurements. We then present the global distributions of $\mathrm{HNO}_{3}$ total columns and we discuss the spatial and temporal variations, with particular focus on polar regions.

\section{Measurements and methods}

\subsection{IASI measurements}

The IASI remote sensor was launched onboard the MetOp sun-synchronous polar orbiting meteorological platform on 19 October 2006 (Clerbaux et al., 2007, 2009). The IASI instrument is a high resolution nadir-viewing Fourier transform spectrometer characterized by an apodized spectral resolution of $0.5 \mathrm{~cm}^{-1}$ and a $0.25 \mathrm{~cm}^{-1}$ spectral sampling. It is designed primarily to measure temperature and water vapor profiles with high accuracy and vertical resolution in the troposphere to benefit atmospheric weather prediction. IASI measures the thermal infrared emission emitted by the Earth-atmosphere system between 645 and $2760 \mathrm{~cm}^{-1}$ with a field of view of $2 \times 2$ circular pixels on the ground, each of $12 \mathrm{~km}$ diameter at nadir. The spectra have low radiometric noise (between $1.2 \times 10^{-7} \mathrm{~W} /\left(\mathrm{m}^{2} \mathrm{sr} \mathrm{m}^{-1}\right)$ around $2200 \mathrm{~cm}^{-1}$ and $2.2 \times 10^{-6} \mathrm{~W} /\left(\mathrm{m}^{2} \mathrm{sr} \mathrm{m}^{-1}\right)$ around $\left.750 \mathrm{~cm}^{-1}\right)$, allowing the simultaneous detection and monitoring of several IR absorbing species (Coheur et al., 2009; Boynard et al., 2009; Clarisse et al., 2009; George et al, 2009; Razavi et al., 2009; Turquety et al., 2009). The IASI measurements are taken at nadir every $50 \mathrm{~km}$ along the trace of the satellite. 
Measurements are also taken across-track over a swath width of $2200 \mathrm{~km}$. Because of its high temporal sampling and large swath width, IASI provides global coverage of the Earth twice daily. It is programmed for a period of 15 years with three successive launches.

\subsection{Radiative transfer model}

In order to handle the large IASI data flow, a fast radiative transfer model has been developed specifically for $\mathrm{HNO}_{3}$,

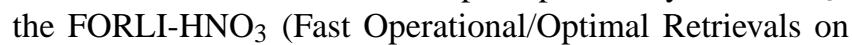
Layers for IASI) software. This software differs significantly from the Atmosphit software (e.g. Barret et al., 2005; Coheur et al., 2005), used in previous $\mathrm{HNO}_{3}$ retrievals from IMG (Wespes et al., 2007) and on a case basis for the present work (Sect. 3.1). FORLI-HNO 3 differs mainly from Atmosphit in that it relies on look-up tables of pre-calculated absorption cross sections at varying pressures and temperatures. Such Look-Up Tables (LUTs) have only been constructed for $\mathrm{HNO}_{3}$ and $\mathrm{H}_{2} \mathrm{O}$ because of the absence of other strong absorbers in the spectral window of interest (see the following section). These tables have been pre-computed from 810 to $960 \mathrm{~cm}^{-1}$ using line parameters from the HITRAN 2004 database with updates beyond 2004 (Rothman et al., 2005) on a logarithmic grid in pressure and a linear grid in temperature and in humidity (for water vapour lines). In order to accurately represent the atmospheric state at each location on the globe, lower and upper limits are respectively set to $162.8 \mathrm{~K}$ and $322.64 \mathrm{~K}$ for temperature and to -10 and 0 for the logarithm of pressure $\left(4.5 \times 10^{-5}\right.$ to $\left.1 \mathrm{~atm}\right)$ with a grid step of $5 \mathrm{~K}$ for temperature and 0.2 for the logarithm of pressure. For water vapour, a third dimension is brought to the grid by considering relative humidity between 0 and 100 and a step of 10 . LUTs have been constructed with a spectral sampling of $0.025 \mathrm{~cm}^{-1}$ (oversampling of $10 \mathrm{vs}$. the $0.25 \mathrm{~cm}^{-1}$ spectral sampling of IASI).

The direct computations of the IASI spectra are then calculated from the LUTs for each location using detailed radiative transfer simulations. The absorbance spectra are convolved with the IASI instrumental line shape, represented by a Gaussian function with $0.5 \mathrm{~cm}^{-1}$ full width at half maximum and then set on the $0.25 \mathrm{~cm}^{-1}$ spectral sampling grid. The relationship between the measured radiances (measurement vector), $\boldsymbol{y}$, and the true atmospheric state (state vector), $\boldsymbol{x}$, is given by $\boldsymbol{y}=\mathbf{F}(\boldsymbol{x}, \boldsymbol{b})+\varepsilon$ where $\mathbf{F}$ is the forward radiative transfer function, $b$ represents model parameters affecting the measurement and $\varepsilon$ is the measurement noise. The radiative transfer function represents the radiance originating from Earth surface, attenuated after passing through the atmosphere, also including the contribution of the average downward flux reflected by the Earth's surface. The radiative transfer calculations use as input the temperature, pressure and humidity profiles provided by EUMETSAT from the operational processing of MetOp sounding observations (Schlüssel et al., 2005). In order to provide the best match with the observations, both the surface temperature and the humidity profiles are included in the state vector for the retrieval step, as discussed in the following section. In addition, surface emissivity taken from climatology based on MODIS/Terra satellite observations at $908 \mathrm{~cm}^{-1}$ (the available channel which is the closest of the $\mathrm{HNO}_{3}$ retrieved spectral range) is considered. Importantly, only cloud-free scenes are considered. The cloud information from the operational processing is used for filtering the observations, and only scenes with cloud coverage below $25 \%$ are analyzed.

\subsection{Retrieval method and settings}

The retrieval of a concentration profile from nadir observations is an ill-conditioned problem that needs to be constrained to provide meaningful results. The retrieval scheme used here is the formalism of the Optimal Estimation Method (OEM) (Rodgers, 2000). Following the latter, an approximation $\hat{\boldsymbol{x}}$ of the true state $\boldsymbol{x}$ (usually a vertical concentration profile) is retrieved from IASI observations using, on one hand, the measurement vector $\boldsymbol{y}$ (here, the IASI radiances) and the associated noise variance-covariance matrix, $\mathbf{S}_{\varepsilon}$, and, on the other hand, a priori information on concentration for the species to be retrieved. The prior information consists of an a priori profile $\boldsymbol{x}_{a}$ and a variance-covariance matrix, $\mathbf{S}_{a}$, that should ideally represent the true variability of the target species in space and time. For a non-linear problem, the retrieved state, $\hat{\boldsymbol{x}}$, is found by iteration of: $\hat{\boldsymbol{x}}_{i+1}=\boldsymbol{x}_{a}+$ $\left(K_{i}^{T} \mathbf{S}_{\varepsilon}^{-1} \mathbf{K}_{i}+\mathbf{S}_{a}^{-1}\right)^{-1} \mathbf{K}_{i}^{T} \mathbf{S}_{\varepsilon}^{-1}\left[\boldsymbol{y}-\mathbf{F}\left(\hat{\boldsymbol{x}}_{i}\right)+\mathbf{K}_{i}\left(\hat{x}_{i}-\boldsymbol{x}_{a}\right)\right]$ where $\mathbf{K}_{i}=(\partial \mathbf{F}(\hat{\boldsymbol{x}}) / \partial \boldsymbol{x})_{i}$ represents the Jacobian matrix. It is computed analytically. The error covariance of the solution is given by $\hat{\mathbf{S}}_{i+1}=\left(\mathbf{K}_{i+1}^{T} \mathbf{S}_{\varepsilon}^{-1} \mathbf{K}_{i+1}+\mathbf{S}_{a}^{-1}\right)^{-1}$. The solution is reached when the absolute difference between every element of $\mathbf{F}$ modeled at two successive iteration steps, $\left|\mathbf{F}\left(\hat{\boldsymbol{x}}_{i+1}\right)-\mathbf{F}\left(\hat{\boldsymbol{x}}_{i}\right)\right|$, is less than a fraction (20\%) of the measurement noise. The logarithmic space has been chosen during the iterative process in order to avoid negative concentrations.

For the retrievals, a wide spectral window extending from 860 to $900 \mathrm{~cm}^{-1}$ that encompasses the $v_{5}$ and $2 v_{9}$ absorption bands of $\mathrm{HNO}_{3}$ is selected. Although these bands are not the most intense absorption features of $\mathrm{HNO}_{3}$ in the thermal infrared, the choice is justified by a limited overlapping from other interfering trace gases in this spectral region. As in previous studies, we consider here a diagonal noise covariance matrix, $\mathbf{S}_{\varepsilon}=\sigma_{\varepsilon}^{2} \mathbf{I}$, with a value $\sigma_{\varepsilon}=2 \times 10^{-6} \mathrm{~W} /\left(\mathrm{m}^{2} \mathrm{sr} \mathrm{m}^{-1}\right)$ close to the expected IASI noise. Similarly, a single $\mathrm{HNO}_{3}$ a priori profile (see Fig. 1) is used: It is built from a set of composite measured and modeled profiles in such a way as to represent a global and annual mean $\mathrm{HNO}_{3}$ profile in the troposphere and the stratosphere. The model profiles from LMDZ-INCA (Hauglustaine et al., 2004) on a $3.75^{\circ}$ longitude $\times 2.50^{\circ}$ latitude grid over one year have been considered to capture tropospheric variability up to $15.6 \mathrm{~km}$. 


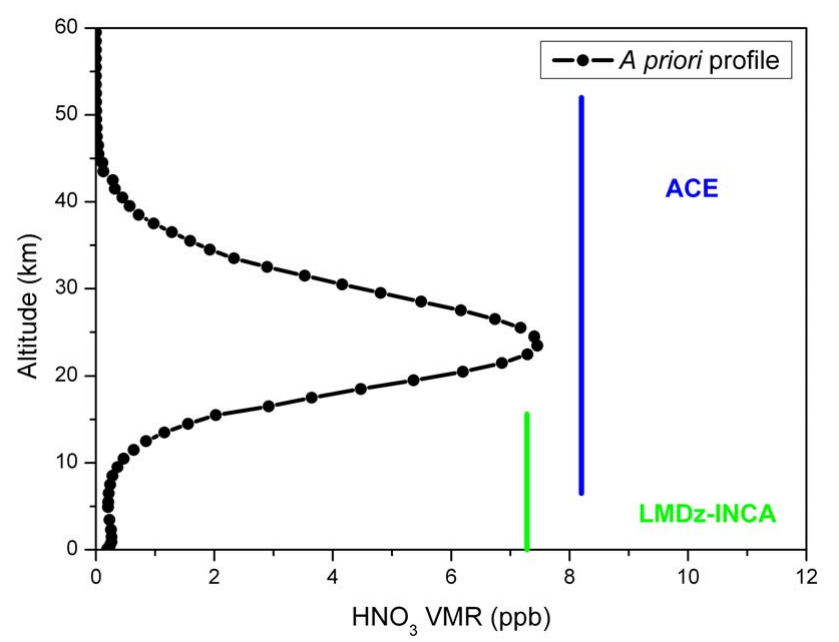

Fig. 1. Global $\mathrm{HNO}_{3}$ a priori profile (black line) constructed from one year of modeled LMDz-INCA profiles from the ground to $15.6 \mathrm{~km}$ (delimited by the green line) and from two years of measured ACE profiles from 6.5 to $60.5 \mathrm{~km}$ (delimited by the blue line).

For the stratosphere up to $60 \mathrm{~km}$, highly resolved vertical profiles measured by the ACE-FTS occultation sounder (Boone et al., 2005) over more than 2 years have been used. The suitable model and measured profiles were resampled on vertical scales and combined to provide an ensemble of profiles from which the mean was computed. For the FORLI$\mathrm{HNO}_{3}$ operational processing, only a total column of $\mathrm{HNO}_{3}$ is retrieved. It has been performed by using a global profile scaling. The choice of retrieving a total column in the operational processing rather than a profile has been established on the basis of full profile retrievals using the line-by-line $A t$ mosphit code (Barret et al., 2005; Coheur et al., 2005). They revealed the absence of vertical sensitivity (see Sect. 3.1) for the IASI $\mathrm{HNO}_{3}$ measurements justifying the operational retrievals of total column for $\mathrm{HNO}_{3}$ in the FORLI-HNO 3 code.

For the FORLI-HNO 3 total column retrievals, a variability of $100 \%$ on the scaling factor to the profile has been considered to characterize $\mathbf{S}_{a}$. In addition to the $\mathrm{HNO}_{3}$ total column, the state vector includes surface temperature and water vapour profiles from the ground to $19 \mathrm{~km}$. Surface emissivity and temperature being strongly correlated, only the surface temperature, which is much more variable, is adjusted. Small-scale variations in the emissivity will thus be compensated by an adjustment of the surface temperature. The retrieval settings are summarized in Table 1 . The retrieved $\mathrm{HNO}_{3}$ product consists of a total column and an associated error computed as $\hat{x}-x=(\hat{S})^{\frac{1}{2}}$ when convergence is reached. The retrieval error includes contributions from the measurement noise, from the limited vertical sensitivity of the measurement, and from the errors on fitted model parameters. They are usually the three main sources of uncertainty for $\mathrm{HNO}_{3}$ retrievals (Wespes et al., 2007).
Table 1. Retrieval settings applied for the operational retrievals of $\mathrm{HNO}_{3}$ total columns using the FORLI-HNO 3 software.

\begin{tabular}{ll}
\hline Spectral range & $860-900 \mathrm{~cm}^{-1}$ \\
\hline $\boldsymbol{x}_{a}$ & $\begin{array}{l}\text { LMDz-INCA (ground } \\
-15.6 \mathrm{~km}) / \mathrm{ACE}(6.5-60.5 \mathrm{~km}) \\
\text { profile }\end{array}$ \\
& $100 \%$ \\
$S_{a}$ & $2 \times 10^{-6} \mathrm{~W} /\left(\mathrm{m}^{2} \mathrm{sr} \mathrm{m}^{-1}\right)$ \\
$\sigma_{\varepsilon}$ & $\begin{array}{l}\mathrm{HNO} \mathrm{total} \\
\text { temperature, Water vapor pro- } \\
\text { file from the ground to } 19 \mathrm{~km} \\
\text { every km }\end{array}$ \\
\hline
\end{tabular}

\subsection{Posteriori filtering}

A posteriori filtering of the data was necessary to remove some strongly biased $\mathrm{HNO}_{3}$ columns. First, filter based on the root mean square (RMS) values of the spectral residuals after the retrievals has been applied. These RMS errors reflect both the error from radiometric noise and from the forward model parameters $\left(\mathrm{HNO}_{3}\right.$, water vapor, temperatures profiles,...). Retrievals with RMS larger than $3 \times 10^{-6} \mathrm{~W} /\left(\mathrm{m}^{2} \mathrm{sr} \mathrm{m}^{-1}\right)$ have been filtered out. Furthermore, we have found that some emissivity features in IASI spectra over deserts, likely associated with calcite, cause an overestimation of the $\mathrm{HNO}_{3}$ total columns. As a result, a postfiltering of these scenes which is directly based on the spectral identification of these emissivity features has also been performed. Note that the filter based on the RMS of the retrievals also helps to discard these contaminated spectra. Finally, in order to exclude measurements with weak sensitivity to the $\mathrm{HNO}_{3}$ total column, we have also removed data characterized by a total error greater than a fraction $(32 \%)$ of $\mathrm{HNO}_{3}$ total column.

\section{Results and discussion}

\subsection{Vertical sensitivity and errors}

In order to evaluate the methodology of the FORLI-HNO 3 processing described above and in particular the choice of global profile scaling for $\mathrm{HNO}_{3}$, we have performed a series of full profile retrievals at representative latitudes using the line-by-line, computationally more demanding, Atmosphit software described elsewhere (Barret et al., 2005; Coheur et al., 2005). Relying on the OEM for the retrieval part, it provides as output all parameters needed for characterizing the retrieved state in terms of vertical sensitivity. The vertical sensitivity is analyzed by means of the averaging 

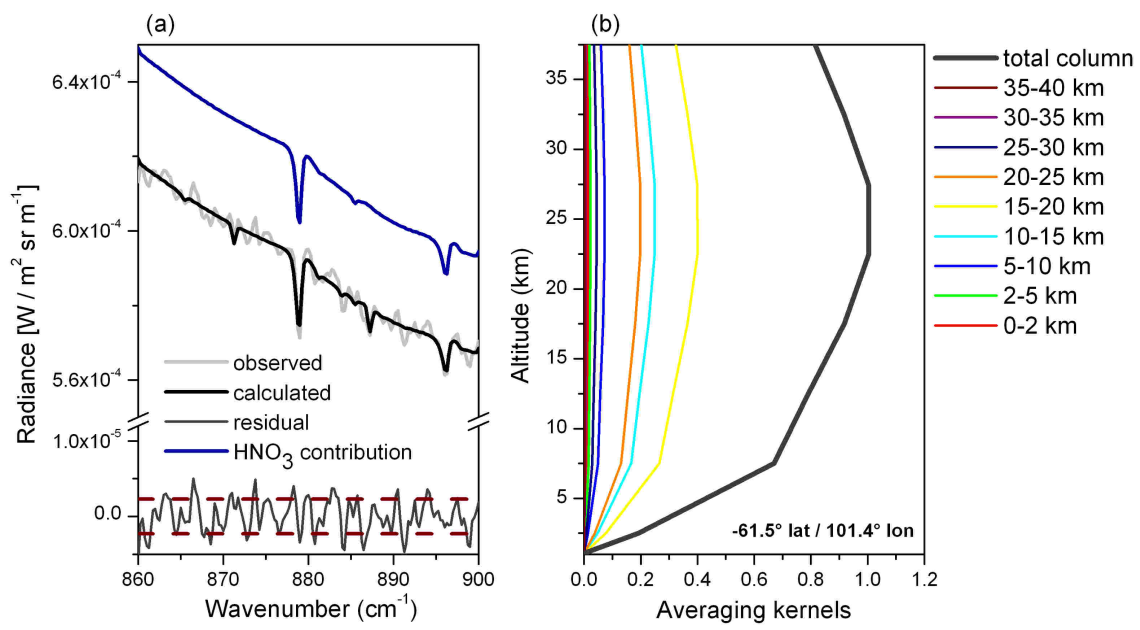

Fig. 2. Left: example of a spectral fit for one typical IASI measurement at polar latitude obtained using Atmosphit code. The light grey and the black lines represent the observed and $\mathrm{HNO}_{3}$ fitted spectra, respectively. The blue line is the adjusted $\mathrm{HNO}_{3}$ contribution and is shifted on the vertical scale for clarity. The residual (observed-fitted spectra) is also drawn. Finally the average RMS value at a global scale $\left(2.3 \times 10^{-6} \mathrm{~W} /\left(\mathrm{m}^{2} \mathrm{sr} \mathrm{m}^{-1}\right)\right)$, associated to residuals after FORLI-HNO 3 retrievals is also shown (dashed horizontal red lines). Right: averaging kernels for this particular retrieval, in partial column units, for nine retrieved layers and for the total column (black).

kernel matrix: $\mathbf{A}=\partial \hat{\boldsymbol{x}} / \partial \boldsymbol{x}=\left(\mathbf{K}^{T} \mathbf{S}_{\varepsilon}^{-1} \mathbf{K}+\mathbf{S}_{\mathbf{a}}{ }^{-1}\right)^{-1} \mathbf{K}^{T} \mathbf{S}_{\varepsilon}^{-1} \mathbf{K}$, the rows of which provide an estimation of the altitude of maximum sensitivity (the peak of the function) and of the vertical resolution (their full width at half maximum). The number of independent pieces of information in the retrieved profiles is calculated as DOFS $=\operatorname{trace}(\mathbf{A})$.

For the purpose of the characterization, identically to Wespes et al. (2007), profiles are retrieved on 9 levels, extending from the ground to $40 \mathrm{~km}$. The a priori profile shown in Fig. 1 is used here in combination with the full variancecovariance matrix built from the same ensemble of profiles, $\mathbf{S}_{\mathbf{a}}$. The resulting a priori variability is maximum at ground level with about $170 \%$ variability, reduces to around $80 \%$ in the troposphere and the lower stratosphere, and strongly decreases down to $30 \%$ above $20 \mathrm{~km}$ in altitude.

Figure 2 shows a typical spectral fit in the selected retrieval window for a polar observation (Fig. 2a) where the amount of water vapor is low and the nitric acid absorption features are clearly identified. A good spectral adjustment is obtained, with a residual (observed-calculated) around the selected value of $\sigma_{\varepsilon}\left(2 \times 10^{-6} \mathrm{~W} / \mathrm{m}^{2} \mathrm{sr} \mathrm{m}^{-1}\right)$. The averaging kernels for the nine retrieval layers and for the total column are shown in Fig. 2b. They all present the same shape covering the entire altitude range from the troposphere to the stratosphere, in agreement with a calculated DOFS of about 1. This result points to the absence of vertical information for $\mathrm{HNO}_{3}$ in the IASI measurements and justifies the retrieval of a total column in the FORLI-HNO 3 processing. The analysis of the averaging kernels further reveals a maximum sensitivity in the lower stratosphere (approximately between 15 and $30 \mathrm{~km}$ ) and a weaker sensitivity close to the surface, which is inherent to thermal IR sounding in the case of low thermal contrast (see Clerbaux et al. (2009), for a more com- plete discussion). These results hold at all latitudes, despite a slightly enhanced vertical sensitivity at tropical latitudes resulting from the higher surface temperatures. The absence of vertical sensitivity to the $\mathrm{HNO}_{3}$ profile as compared to our previous work on IMG (Wespes et al., 2007) clearly points to the coarser spectral resolution of IASI $\left(0.5 \mathrm{~cm}^{-1}\right.$ as compared to $0.1 \mathrm{~cm}^{-1}$ ) which does not sufficiently resolve the spectral lines.

Based on these results, we decided to retrieve only a total column by a global profile scaling for $\mathrm{HNO}_{3}$ in the op-

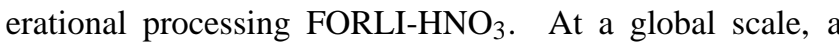
good spectral adjustment is obtained using this method: the RMS values of the spectral residuals from FORLI-HNO 3 range from $1.5 \times 10^{-6} \mathrm{~W} / \mathrm{m}^{2} \mathrm{sr} \mathrm{m}^{-1}$ to the threshold value of $3 \times 10^{-6} \mathrm{~W} / \mathrm{m}^{2} \mathrm{sr} \mathrm{m}^{-1}$, with on average RMS values of about $2.3 \times 10^{-6} \mathrm{~W} / \mathrm{m}^{2} \mathrm{sr} \mathrm{m}^{-1}$ (represented on Fig. 2a by dashed red lines). Note that the RMS values are close to the selected value of $\sigma_{\varepsilon}\left(2 \times 10^{-6} \mathrm{~W} / \mathrm{m}^{2} \mathrm{sr} \mathrm{m}^{-1}\right)$ used to constrain the retrievals. Larger RMS values are observed at Equatorial regions due to higher concentrations of water vapor and the highest values are principally visible over deserts due to sharp emissivity features (see Sect. 2.4). The errors on the FORLI retrieved $\mathrm{HNO}_{3}$ total columns are strongly variable on the globe, ranging from a few percent up to the threshold value of $32 \%$ (see previous section) with on average values of about $12 \%$. We found larger errors principally in the equatorial belt. This can be explained by the impact of water vapor lines which strongly interfere with $\mathrm{HNO}_{3}$ features at the equator. High errors are also visible at polar latitudes principally over very cold or icy surfaces, possibly due to the weaker sensitivity to $\mathrm{HNO}_{3}$ measurements at the poles due to weaker radiances or due to possible emissivity issues over such surfaces. 

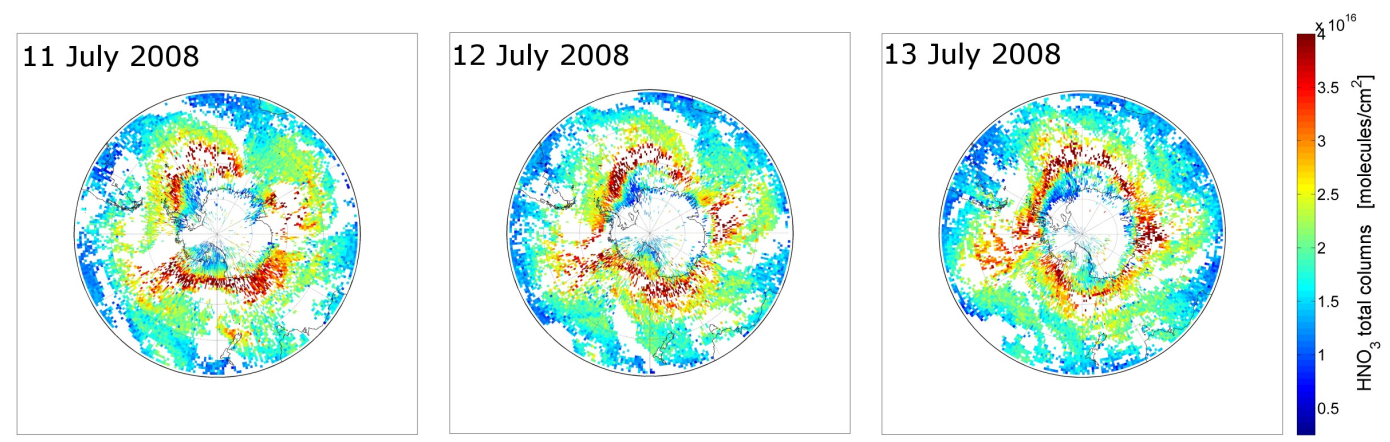

Fig. 3. Antarctic projections of IASI $\mathrm{HNO}_{3}$ total columns retrieved from FORLI near-real-time processing for three successive days in July 2008. Data have been gridded on $1^{\circ} \times 1^{\circ}$. White areas result from the applied filters (Sect. 2.4).

\subsection{Global distributions}

This section presents and discusses the results from the operational processing of IASI data using FORLI, to retrieve total column for $\mathrm{HNO}_{3}$. Analysis of the IASI spectra after the cloud and posteriori filterings (on average $10-15 \%$ of IASI spectra are conserved) provides quasi-global distributions daily, with a horizontal resolution and temporal sampling never achieved before. In order to shed light on these small-scale variations, Fig. 3 presents $\mathrm{HNO}_{3}$ total column distributions in the Southern Hemisphere for 3 successive days, with columns averaged on a $1^{\circ} \times 1^{\circ}$ grid. Obviously, the IASI concentration fields contain a wealth of information that will be useful to analyze local chemical and physical processes in Earth's low atmosphere. Such analyses have not yet been performed, and the remainder of this section focuses instead on large scale features that are better observed by averaging over several days.

As a first example, Figs. 4 and 5 show the monthly evolution of the global distributions of $\mathrm{HNO}_{3}$ from March 2008 to February 2009 in polar orthographic projections, respectively for the Southern and Northern Hemispheres. For each month, the data are averaged on $1^{\circ} \times 1^{\circ}$ grid, only over a series of successive days (see Table 2 ), in order to highlight as much as possible the temporal dependence of $\mathrm{HNO}_{3}$ abundances. The same set of days is not used for all months because of instrument sampling issues (data gaps). Figure 4 also shows two temperature isocontours of $195 \mathrm{~K}$ and $188 \mathrm{~K}$ (in blue lines) observed at $50 \mathrm{hPa}$, which are found in the range of altitude characterized by the maximal sensitivity of the measurements (see previous section). The $195 \mathrm{~K}$ and $188 \mathrm{~K}$ temperatures are found inside the polar vortex and correspond to the thresholds for type 1 and type 2 PSC formation, respectively. Values of potential vorticity (PV) at the potential temperature of $520 \mathrm{~K}$ $(\sim 50 \mathrm{hPa})$ gathered from the Met Office fields ${ }^{1}$ for MLS analyses have further been used to represent the size, the shape and the strength of the polar vortex and are superim-

\footnotetext{
${ }_{1}$ available at: https://mls.jpl.nasa.gov/dmp/
}

Table 2. Selection of successive days within each month from March 2008 to February 2009, used to draw the zonal distributions of Figs. 4 and 5.

\begin{tabular}{lr}
\hline Months & Selected days \\
\hline March & $1-7$ \\
April & $9-15$ \\
May & $9-15$ \\
June & $10-13$ \\
July & $9-15$ \\
August & $8-10$ \\
September & $6-9$ \\
October & $14-20$ \\
November & $9-15$ \\
December & $17-23$ \\
January & $15-19$ \\
February & $21-25$ \\
\hline
\end{tabular}

posed as black lines in Figs. 4 and 5. As can be seen from Figs. 4 and 5, the IASI measurements capture the large scale variations of $\mathrm{HNO}_{3}$ with latitude: low values characterized by a total column down to about $1 \times 10^{16}$ molecules $/ \mathrm{cm}^{2}$ on average are found in the intertropical belt, progressively increasing towards polar regions, where they approach $4.5 \times 10^{16}$ molecules $\mathrm{cm}^{-2}$. This behavior is observed for all seasons as will be discussed in greater detail below. The only exception to this gradient occurs in the Southern Hemisphere winter and spring (June to December), when denitrification inside the Antarctic polar vortex produces a strong decrease of the column down to $1 \times 10^{16}$ molecules $\mathrm{cm}^{-2}$. The distributions shown in Figs. 4 and 5 reveal also large seasonal variability at the highest latitudes in both hemispheres, in contrast to the tropical and middle latitudes, where monthly variations are not observed. As a general rule, except in the PSC-formation regions, we find at high latitudes weaker concentrations in summer and higher abundances in fall and wintertime. For example, the concentrations at 


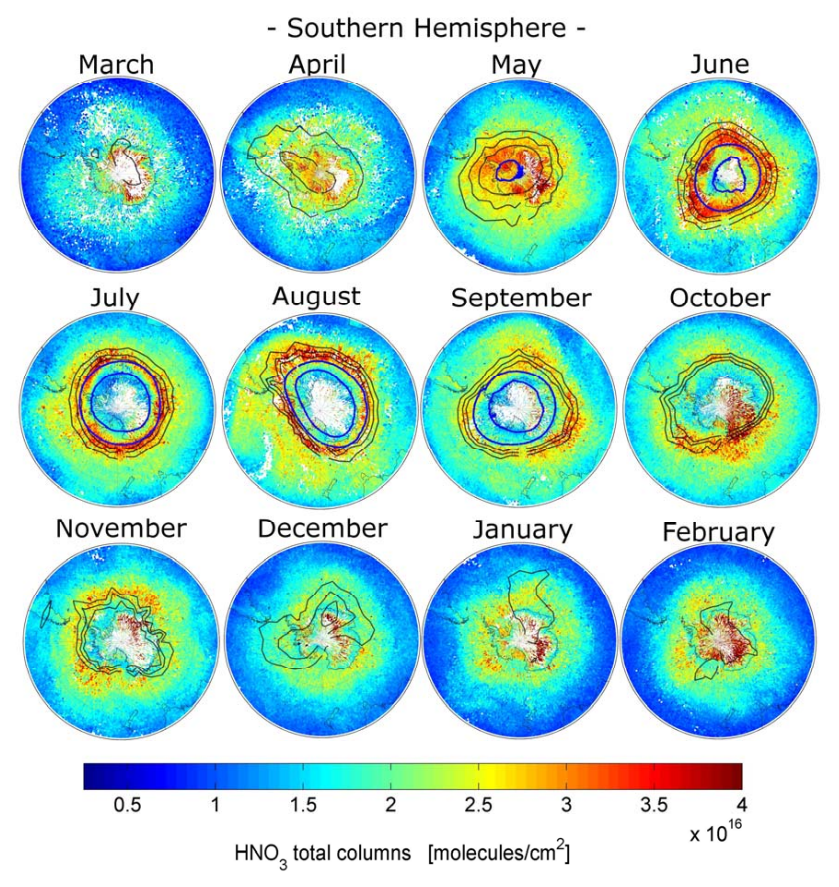

Fig. 4. Polar projections of $\mathrm{IASI} \mathrm{HNO}_{3}$ total columns for the Southern Hemisphere. Data are gridded on $1^{\circ} \times 1^{\circ}$ by averaging selected days within each month from March 2008 to February 2009 (see Table 2). Three contours of Met Office potential vorticity at a potential temperature of $520 \mathrm{~K}$ are superimposed as black lines. The $-0.60 \times 10^{-4} \mathrm{~K} \mathrm{~m}^{2} \mathrm{~kg}^{-1} \mathrm{~s}^{-1}$ contour represents approximately the edge of the Antarctic winter polar vortex at this level. Other contours have been added $\left(-0.50 \times 10^{-4} \mathrm{~K} \mathrm{~m}^{2} \mathrm{~kg}^{-1} \mathrm{~s}^{-1}\right.$ and $-0.40 \times 10^{-4} \mathrm{~K} \mathrm{~m}^{2} \mathrm{~kg}^{-1} \mathrm{~s}^{-1}$ ) to evaluate the size and the strength of the polar vortex. The contours of $195 \mathrm{~K}, 188 \mathrm{~K}$ temperature at $50 \mathrm{hPa}(\sim 20 \mathrm{~km})$ taken from Eumetcast level 2 data are also indicated by blue lines for the appropriate months.

chosen mid-latitude (Moshiri, $44^{\circ} \mathrm{N}, 142.3^{\circ} \mathrm{E}$ ) and polar sites (Ny Alesund, $78.9^{\circ} \mathrm{N} 11.9^{\circ} \mathrm{E}$ ) in the Northern Hemisphere vary on average between $2.50 \times 10^{16}$ molecules $\mathrm{cm}^{-2}$ in January to $1.35 \times 10^{16}$ molecules $\mathrm{cm}^{-2}$ in July and between $3.15 \times 10^{16}$ molecules $\mathrm{cm}^{-2}$ in January to $1.89 \times 10^{16}$ molecules $\mathrm{cm}^{-2}$ in July, respectively. These large-scale spatial and seasonal variations in the $\mathrm{HNO}_{3}$ total columns are fully consistent with the photochemical processes occurring in the stratosphere (Austin et al., 1986; Rinsland et al., 1991; Santee at al., 1999 and references therein, Santee et al., 2004; Urban et al., 2008, among others).

As already pointed out above, a remarkable pattern appearing in the spatial and monthly distributions of the $\mathrm{HNO}_{3}$ total columns is the strong depression found inside the Southern Hemisphere polar vortex during winter and spring. During this period (June to October), the temperatures in the stratosphere are indeed cold enough to form PSCs of type 1 (from $195 \mathrm{~K}$ ) and of type 2 (from $188 \mathrm{~K}$ ). This causes local denitrification inside the vortex and leads at the same time to a col-

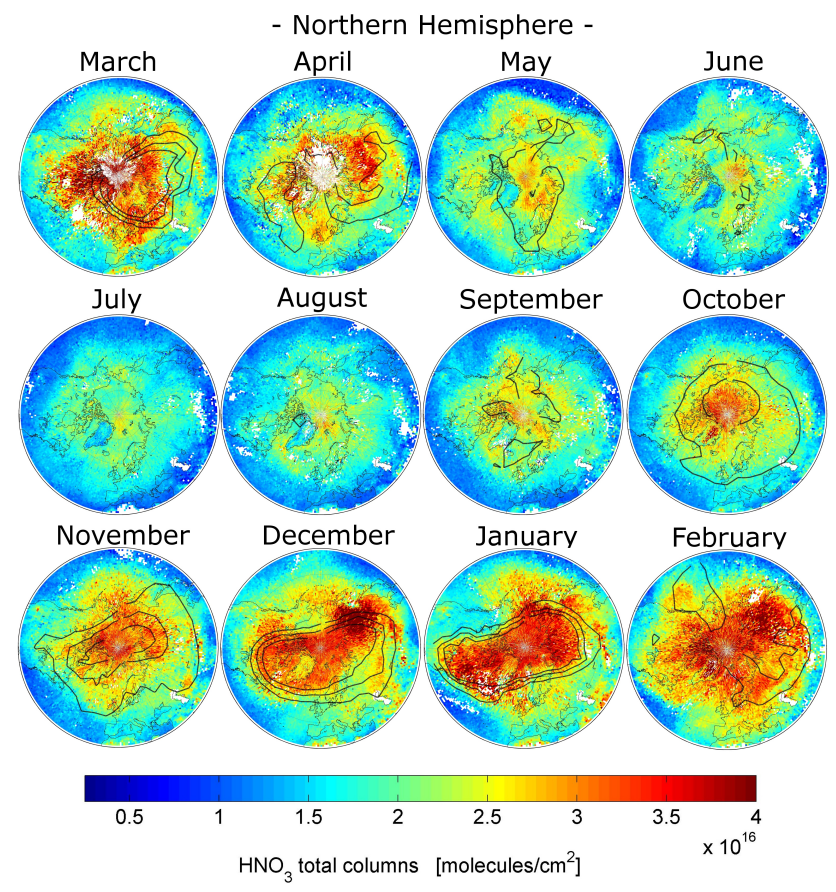

Fig. 5. Same as in Fig. 4, but for the Northern Hemisphere. Three contours of Met Office potential vorticity at a potential temperature of $520 \mathrm{~K}$ are superimposed as black lines $\left(+0.60 \times 10^{-4} \mathrm{~K} \mathrm{~m}^{2} \mathrm{~kg}^{-1} \mathrm{~s}^{-1},+0.50 \times 10^{-4} \mathrm{~K} \mathrm{~m}^{2} \mathrm{~kg}^{-1} \mathrm{~s}^{-1}\right.$ and $\left.+0.40 \times 10^{-4} \mathrm{~K} \mathrm{~m}^{2} \mathrm{~kg}^{-1} \mathrm{~s}^{-1}\right)$.

lar region of enhanced $\mathrm{HNO}_{3}$ concentrations at and around the vortex edge. The strong depletion of $\mathrm{HNO}_{3}$ starts in June when temperatures fall below the type 2 PSC threshold and reaches a maximum during July. The $\mathrm{HNO}_{3}$-rich air region is found at and around the polar vortex, which is highlighted in Fig. 4 by contours of PV (black lines) at the potential temperature level of $520 \mathrm{~K}$. During the period analyzed in this work, temperatures in the Arctic were not low enough to lead to denitrification.

In order to further illustrate the seasonal variations of the $\mathrm{HNO}_{3}$ columns with latitude, Fig. 6 presents a time series of total columns from March 2008 to February 2009, with the IASI data gridded on 1 day $\times 1^{\circ}$. A transition in total column values during July is observed, which corresponds to changes, in the forward model function, during this work. The isocontours of $195 \mathrm{~K}, 188 \mathrm{~K}$ for temperature at 50 and $15 \mathrm{hPa}(\sim 20$ and $25 \mathrm{~km})$ and three different values for potential vorticity are also shown. The hemispheric differences in the total columns already appearing from the zonal projections in Figs. 4 and 5 are highlighted, showing maxima around $4.5 \times 10^{16}$ molecules $\mathrm{cm}^{-2}$ during January in the Northern Hemisphere and around $5 \times 10^{16}$ molecules $\mathrm{cm}^{-2}$ during May in the Southern Hemisphere. These high values above Antarctica are found in the collar region at and around the vortex edge, as explained above. The temporal trend is in agreement with previous work reporting on 


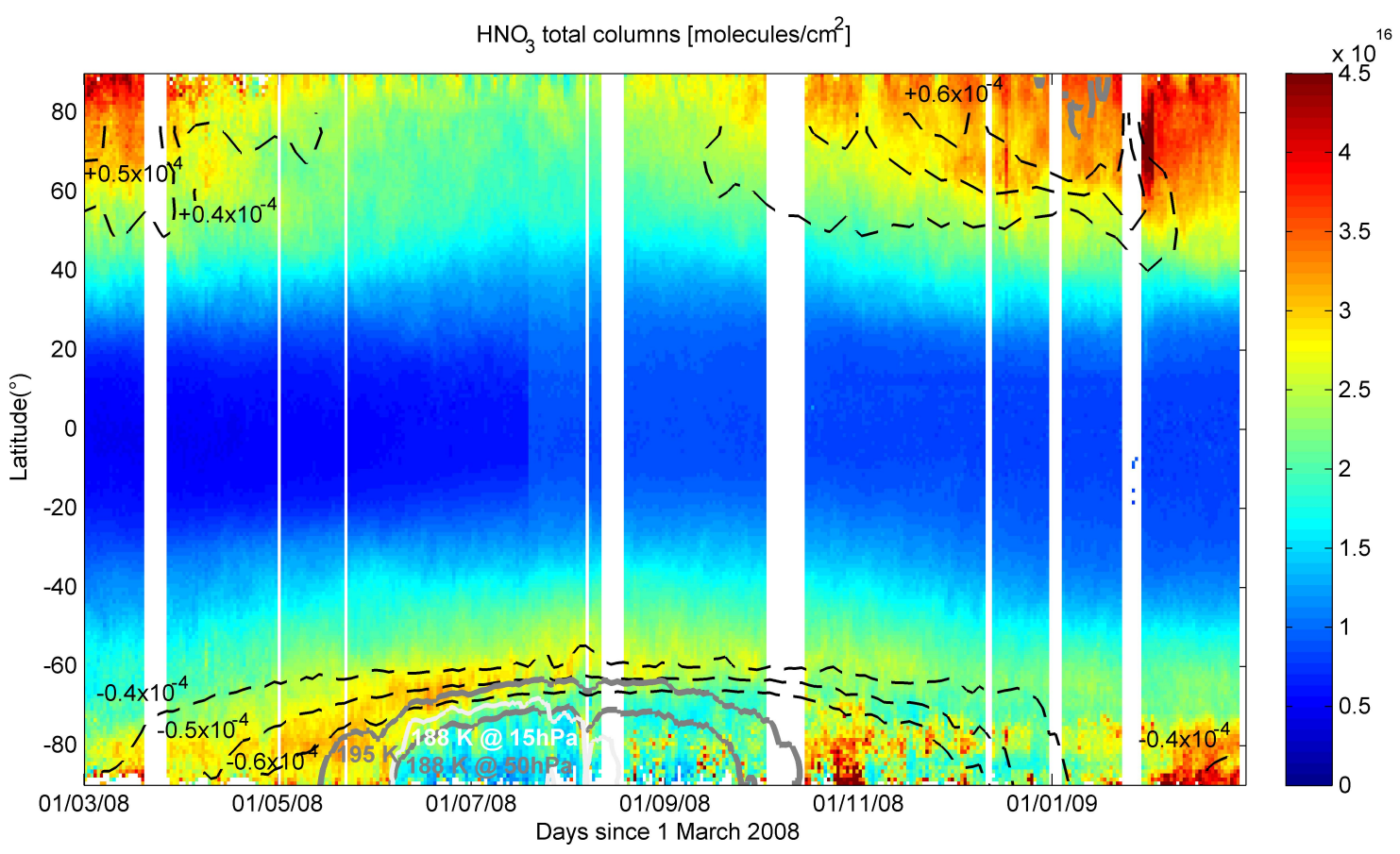

Fig. 6. Time series of IASI $\mathrm{HNO}_{3}$ total columns (molecules $\mathrm{cm}^{-2}$ ) as a function of latitude, obtained by averaging data on a 1 day $\times 1^{\circ}$ grid. The isocontours of $195 \mathrm{~K}, 188 \mathrm{~K}$ for temperature at 50 (grey lines) and $15 \mathrm{hPa}$ (white line) ( 20 and $25 \mathrm{~km})$ taken from Eumetcast level 2 data are plotted along with three different contours of potential vorticity as in Figs. 4 and 5.

the long-term evolution of global stratospheric distributions measured by UARS/MLS and Odin/SMR satellites (Santee et al., 2004; Urban et al., 2008). Figure 6 highlights again the fact that the distributions over the polar regions are governed by the strength and the spatial extent of the polar vortices as well as the lowest stratospheric temperatures, which control PSC formation. Interestingly, a closer look into this region of widespread denitrification reveals $\mathrm{HNO}_{3}$ values markedly higher than expected at the end of August and which are persistent for several days in spite of the low temperature at 50hPa (grey lines in Fig. 6). A possible explanation could be the warming of the stratosphere at higher altitudes (for example, isocontour of $188 \mathrm{~K}$ at $15 \mathrm{hPa}$ shown as a white line on Fig. 6) well above the PSC formation thresholds, causing the PSC particles to evaporate and to release $\mathrm{HNO}_{3}$ in the gas phase.

Figure 7 presents similar time series of $\mathrm{HNO}_{3}$ total columns over the 12 months analyzed here, but for $1^{\circ}$ latitude $\times 2^{\circ}$ longitude grid boxes around six specific locations representative of polar (Fig. 7a and b), middle (Fig. 7c and d) and equatorial (Fig. 7e and f) latitudes in both Northern and Southern Hemispheres. The average temporal trend is given by the white curve, while the light grey area represents daily variations in the spatial grid box. $3 \sigma$ values ( $\sigma$ being the daily standard deviation of the retrieved total columns) are considered to represent the daily variations. Daily variations of the total columns are at a global scale larger than the uncertainties associated to the total columns.
For instance, for the specific locations representative of polar regions, the $3 \sigma$ retrieval error is on average around $30 \%$ whereas the daily variability is on average around 50-60\% and can be as high as $170 \%$. This daily variability can mainly be attributed to the rapid zonal transport of air masses in these regions as observed for example on Fig. 3. For the locations representative of the equatorial belt, the $3 \sigma$ retrieval error are much closer to the daily variability, which amounts 45$50 \%$. As a result, less confidence should be attributed to the daily variations in the tropical regions than in the polar/midlatitude regions. It is also worth pointing out that, in the tropical regions, the stratospheric columns are smaller than at mid and polar latitudes, making the tropospheric contribution to the total columns more significant. The equatorial daily variations at Manau Loa and Reunion Island (Fig. 7e and f) could therefore partly be attributed to tropospheric daily variations.

$\mathrm{HNO}_{3}$ mixing ratios of MLS at the pressure level of $46.5 \mathrm{hPa}$ measured at the same locations are superimposed for the purpose of comparison. A detailed description of the MLS $\mathrm{HNO}_{3}$ level 2 products is provided by Froidevaux et al. (2006) and by Santee et al. (2007). As discussed above, the amplitude of the seasonal cycle is negligible at equatorial latitudes and becomes progressively stronger towards the poles. We note however a slight trend of the total columns at Reunion Island (Fig. 7f) which is not apparent at Mauna Loa (Fig. 7e). At middle latitudes, both in the Northern and in the Southern Hemispheres, higher values are found in the wintertime and lower values during summer, with the amplitude of 

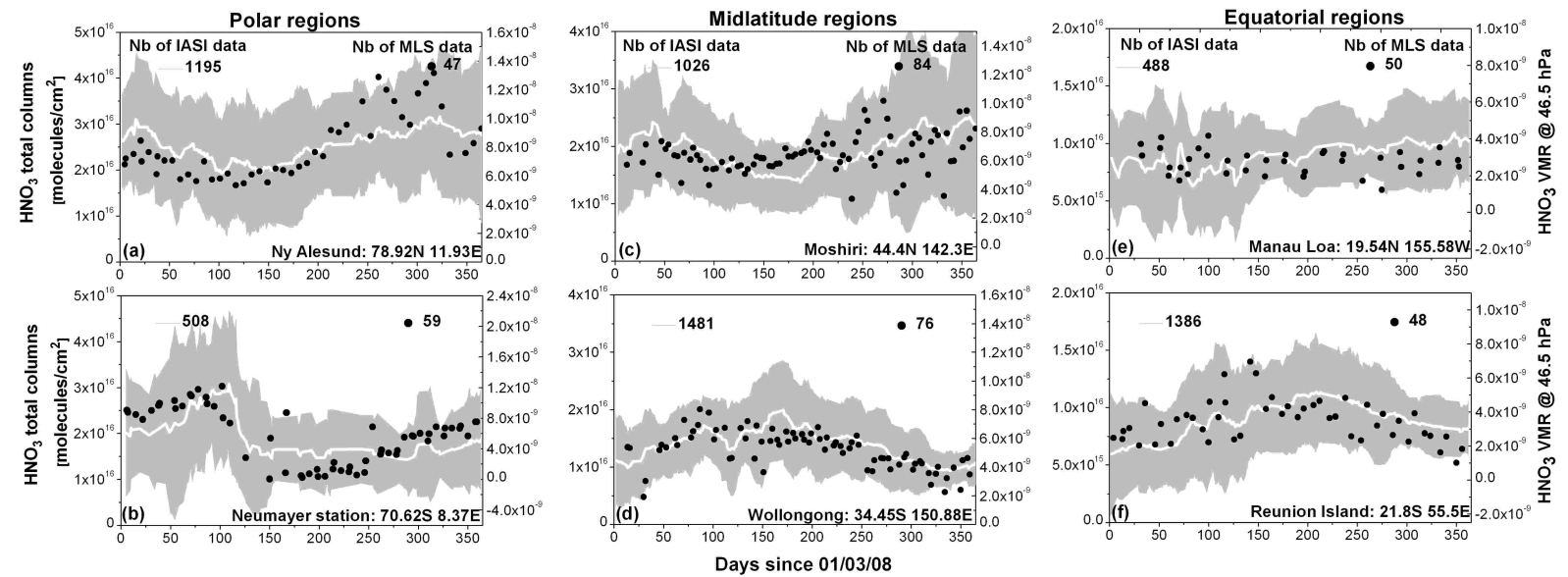

Fig. 7. Time series of IASI $\mathrm{HNO}_{3}$ total columns for $1^{\circ}$ latitude $\times 2^{\circ}$ longitude area around six selected NDACC (Network for the Detection of Atmospheric Composition Change) stations in polar (a, b), midlatitude (c, d) and equatorial (e, f) regions. The daily average trend is shown as a white line. The grey area represents $3 \sigma$, where $\sigma$ is the standard deviation around the daily average within the grid box. $\mathrm{HNO}_{3}$ volume mixing ratios at $46.5 \mathrm{hPa}(\sim 20 \mathrm{~km})$ (right axis) retrieved from co-located MLS/Aura are superposed for a sake of comparison.
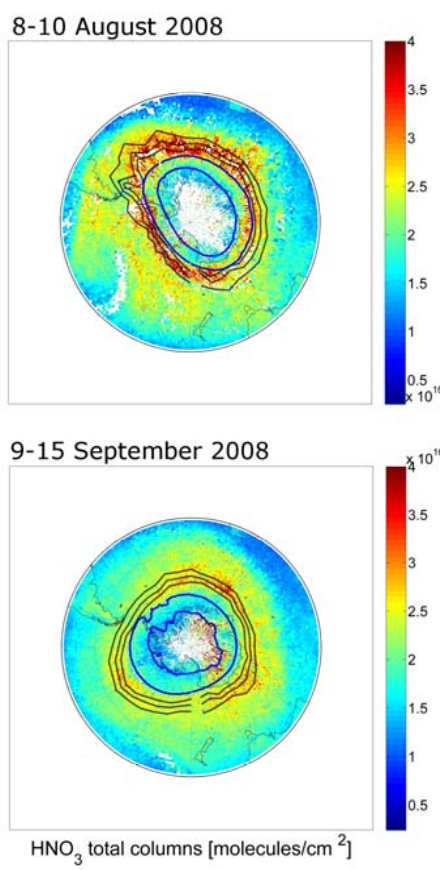
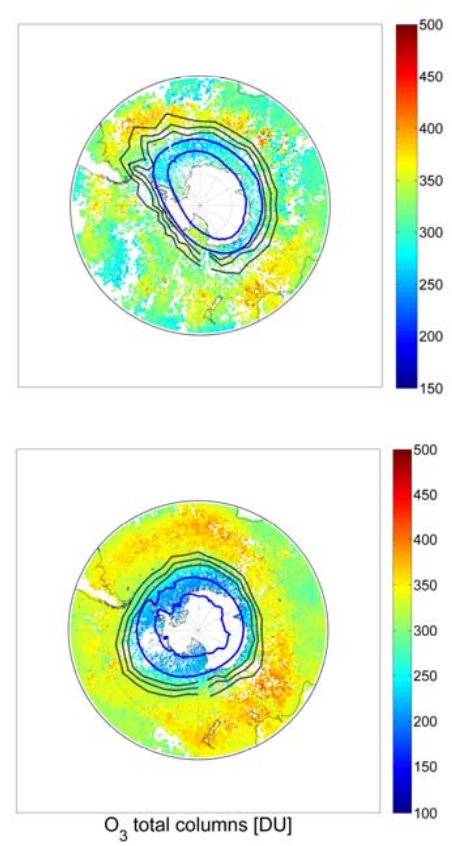
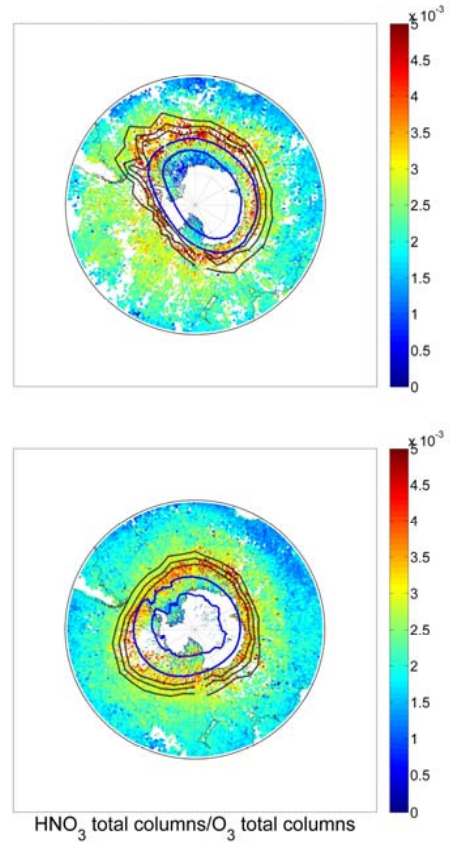

Fig. 8. Southern Hemispheric polar projections of IASI $\mathrm{HNO}_{3}, \mathrm{O}_{3}$ total columns and $\mathrm{HNO}_{3} / \mathrm{O}_{3}$ ratios for two periods characterized by depletion of $\mathrm{HNO}_{3}$ and/or $\mathrm{O}_{3}$. As in Plate 4, contours of Met Office potential vorticity at a potential temperature of $520 \mathrm{~K}$ and temperature contours of 195 and $188 \mathrm{~K}$ at $50 \mathrm{hPa}$ are shown.

the seasonal cycles around $1 \times 10^{16}$ molecules $\mathrm{cm}^{-2}$. These seasonal variations are partly masked by the extent of daily variability, with the $3 \sigma$ value of the daily standard deviation in the grid box being twice as large as the amplitude of the seasonal variations. We also note a very different behavior between the Northern and the Southern polar latitudes. In the Arctic, the seasonal variations are strongly masked by the daily variations, which reach $3 \times 10^{16}$ molecules $\mathrm{cm}^{-2}$ $(3 \sigma)$, whereas in the Antarctic, the particular behavior of $\mathrm{HNO}_{3}$ inside and around the polar vortex core is clearly visible. Overall, the seasonal and latitudinal variations of total columns are in agreement with those of MLS mixing ratios at $46.5 \mathrm{hPa}$ in the stratosphere, emphasizing again the very dominant contribution of the stratospheric component to 


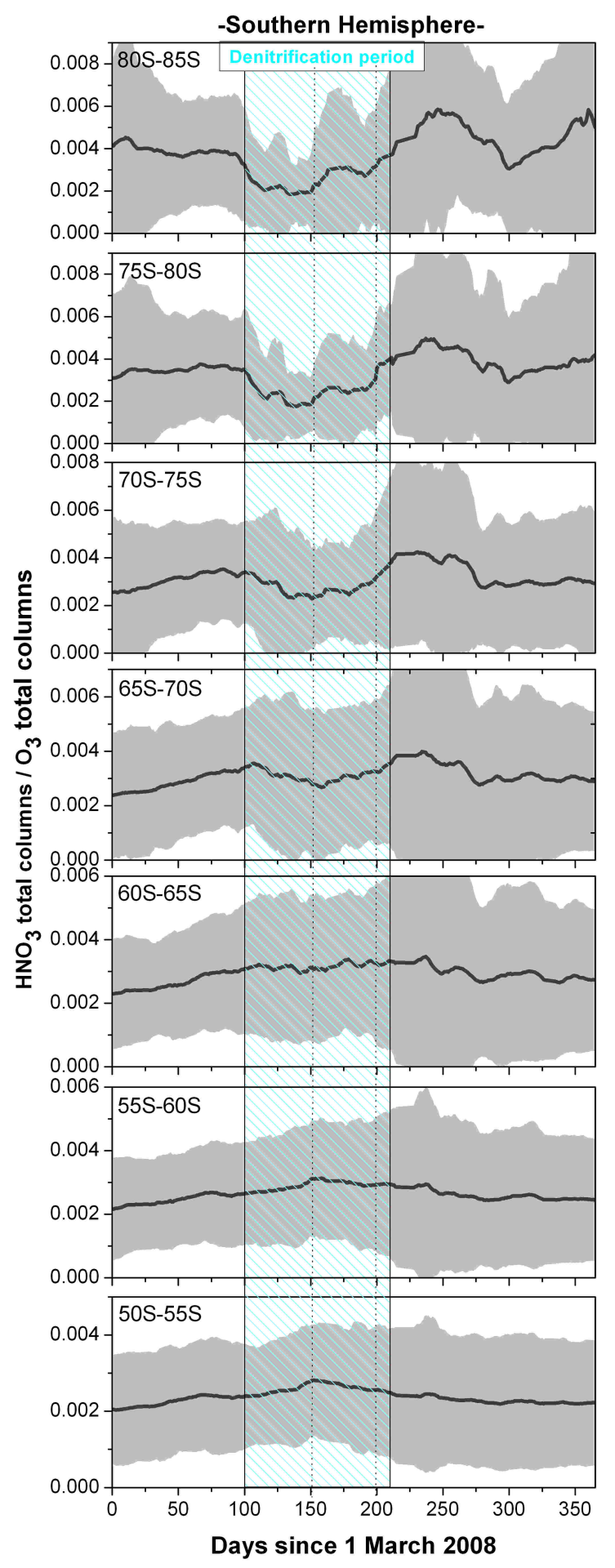

Fig. 9. Time series of $\mathrm{HNO}_{3} / \mathrm{O}_{3}$ total column ratio for 7 latitude bands in the Southern Hemisphere. The daily average trend of the ratio is shown as a black line. The grey area represents $3 \sigma$ where $\sigma$ is the standard deviation around the average. The blue area defines the period of strong denitrification. The two dashed lines inside this blue area highlight the period selected for Plate 8 . the IASI measured total column. Differences between IASI and MLS data are obviously expected in regard to different sampling and observing geometry. It is worth pointing out that, even at equatorial regions where the retrievals errors of the IASI measurements can partly made the daily variations, the time series are consistent with those of MLS mixing ratios. The most remarkable gain of IASI as compared to limb sounders such as MLS lies in the number of measurements which allows monitoring the daily as well as the small-scale spatial variations. This different number of data within the selected boxes can constitute an important source of discrepancies in the comparison. As a result, the comparisons with MLS constitute only a good qualitative validation of IASI colums. A quantitative validation of the IASI measured total columns is not possible at this stage due to the absence of archived data from ground based measurements. We note, however, that the range of values reported here is consistent with extensive measurements made recently in the frame of MIPAS validation (Vigouroux et al., 2007).

\subsection{Preliminary comparison with $\mathrm{O}_{3}$ total columns}

One of the strengths of the IASI mission for atmospheric chemistry lies in the simultaneous measurement of about 10 species with excellent horizontal resolution. Of particular relevance for $\mathrm{HNO}_{3}$ chemistry in both the stratosphere and troposphere is the relationship with ozone. Figure $8 \mathrm{com}$ pares the Southern Hemispheric global distributions respectively of $\mathrm{HNO}_{3}$ and $\mathrm{O}_{3}$ total columns for two periods characterized by depletion of $\mathrm{HNO}_{3}$. The IASI $\mathrm{O}_{3}$ fields are also retrieved in a near real time mode. For a full description of the ozone product the reader should refer to Turquety et al. (2004) and Massart et al. (2009). Contours of potential vorticity and temperatures of PSC formation are superimposed on the maps, as in Figs. 4 and 5. The first illustrated period, 8-10 August 2008, is characterized by significant denitrification inside the polar vortex (see the previous section) but is prior to the ozone hole development. As a result, the $\mathrm{HNO}_{3} / \mathrm{O}_{3}$ ratios (top right panel in Fig. 8) are characterized by elevated values (about $5 \times 10^{-3}$ ) in the collar region circling the vortex and very low values (about $5 \times 10^{-4}$ ) inside the denitrified vortex core. During the second period in early spring, 9-15 September, the ozone hole is close to its maximum and both the $\mathrm{HNO}_{3}$ and $\mathrm{O}_{3}$ total columns inside the vortex show lower values. The resulting $\mathrm{HNO}_{3} / \mathrm{O}_{3}$ ratios (bottom right panel in Fig. 8) show somewhat less latitudinal variation (between $1 \times 10^{-3}$ and $4 \times 10^{-3}$ on average) than for the August period, even though the $\mathrm{HNO}_{3}$ rich collar region remains still clearly apparent. Figure 9 shows the evolution of the $\mathrm{HNO}_{3} / \mathrm{O}_{3}$ ratios in $5^{\circ}$ latitude bands from 50 to $85^{\circ} \mathrm{S}$ for the 12 months analyzed here. On a daily average basis, the ratio values vary between $1.5 \times 10^{-3}$ and $6 \times 10^{-3}$. Minimum values are found during the denitrification period prior to the stratospheric ozone hole formation (see shaded blue area in Fig. 9) at lower latitudes. At the end of the polar night, 
the values of the ratio are increasing because of the ozone losses. During this period, higher ratios can be observed with values reaching 0.012 . For all latitudes, the temporal average trend in the $\mathrm{HNO}_{3} / \mathrm{O}_{3}$ ratios is again weaker than the extent of daily variation. We also note that, except for the denitrification period, the $\mathrm{HNO}_{3} / \mathrm{O}_{3}$ ratio increases on average with latitude, pointing to the larger latitudinal gradient of $\mathrm{HNO}_{3}$ as compared to that of ozone. The $\mathrm{HNO}_{3} / \mathrm{O}_{3}$ ratios obtained from IASI measurements are in agreement with previous studies which report values ranging from $1.8 \times 10^{-3}$ to $9 \times 10^{-3}$ in the lower stratosphere (Trainer et al., 1993; Bregman et al., 1995; Talbot et al., 1997; Schneider et al., 1999; Neuman et al., 2001).

\section{Summary and conclusions}

Nitric acid total columns have been retrieved globally from IASI measurements in a dedicated window $\left(860-900 \mathrm{~cm}^{-1}\right)$ despite the weakness of the signal, but without any vertical information. The FORLI-HNO 3 (Fast Operationnal Retrievals on Layers for IASI) software, a fast radiative transfer model coupled to an inversion software relying on the Optimal Estimation Method, has been developed to retrieve $\mathrm{HNO}_{3}$ total columns in near-real time. The resulting product has been thoroughly described here. Global distributions have been retrieved daily for a one year period starting from March 2008, providing an unprecedented view of the nitric acid fields and their seasonal and inter-hemispheric variations. Estimated errors on the total columns are found to be highly variable. We have shown that IASI measurements capture the hemispheric gradient from low values at the equator to higher values toward the poles. The amplitude of the seasonal variations is negligible at tropical latitudes and becomes pronounced at middle and polar latitudes. Overall, larger $\mathrm{HNO}_{3}$ columns are measured in fall and winter polar regions and lower values are found in summertime, resulting from more active photochemistry. However, we have shown that daily variations of the total columns in small grid boxes are relatively important and partly mask the seasonal variations. Beside the general variations with season and latitude, the remarkable denitrification processes occurring in the winter polar region when temperatures are low enough to form PSCs have been observed in the Antarctic between June and December 2008. Polar regions exhibit well the fact that the wintertime $\mathrm{HNO}_{3}$ distributions are governed by the strength and the spatial extent of the polar vortex as well as by the lowest temperatures, which control the formation of PSC particles.

Overall, the seasonal variations observed are representative of stratospheric processes. Initial qualitative comparisons with MLS measurements of $\mathrm{HNO}_{3}$ in a lower stratospheric layer at specific locations have been performed. The seasonal variations of total columns are in agreement with those of MLS mixing ratios in the stratosphere. The most remarkable gain of IASI lies in the number of measurements, which allows monitoring daily and small-scale spatial variations. A preliminary comparison between $\mathrm{HNO}_{3}$ and $\mathrm{O}_{3}$ distributions at high latitudes in the Southern Hemisphere has been conducted in order to illustrate the potential of IASI to contribute to further global and small-scale analyses of chemical processes, such as those occurring in the Antarctic vortex. The distributions of $\mathrm{HNO}_{3}$ and $\mathrm{O}_{3}$ were compared for periods characterized by depletion of $\mathrm{HNO}_{3}$ at polar latitudes. Time series of the $\mathrm{HNO}_{3} / \mathrm{O}_{3}$ ratios have been analyzed. On average, the ratios vary from $1.5 \times 10^{-3}$ to $6 \times 10^{-3}$ with minimum values in the severely denitrified region.

The results presented here open further perspectives. In particular, long-term time-series are expected, given the 15 years of the IASI program, which will allow an analysis of inter-annual variability. Furthermore, work is in progress to isolate the tropospheric $\mathrm{HNO}_{3}$ contribution from the IASI spectra, through combination with other satellite instruments and data assimilation.

Acknowledgements. IASI has been developed and built under the responsibility of the Centre National d'Etudes Spatiales (CNES, France). It is flown onboard the Metop satellites as part of the EUMETSAT Polar System. The IASI L1 data are received through the EUMETCast near real time data distribution service. The research was funded by the Fonds National de la Recherche Scientifique (FNRS, Belgium M.I.S. F.4511.08), the Belgian State Federal Office for Scientific, Technical and Cultural Affairs and the European Space Agency (ESA-Prodex arrangement C90-327). Financial support by FRIA and the "Communauté Française de Belgique-Actions de Recherche Concertées" and are also acknowledged. Work at the Jet Propulsion Laboratory, California Institute of Technology, was done under contract with the National Aeronautics and Space Administration.

Edited by: T. Wagner

\section{References}

Adams, P. J., Seinfeld, J. H., Koch, D. M., Mickley, L. J., and Jacob, D. J.: General circulation model assessment of direct radiative forcing by the sulfate-nitrate-ammonium-water inorganic aerosol system, J. Geophys. Res., 106, 1097-1111, 2001.

Austin, J., Garcia, R., Russel-11l, J., Solomon, S., and Tuck, A.: On the atmospheric photochemistry of nitric acid, J. Geophys. Res., 91, 5477-5484, 1986.

Barret, B., Turquety, S., Hurtmans, D., Clerbaux, C., Hadji-Lazaro, J., Bey, I., Auvray, M., and Coheur, P.-F.: Global carbon monoxide vertical distributions from spaceborne high-resolution FTIR nadir measurements, Atmos. Chem. Phys., 5, 2901-2914, 2005, http://www.atmos-chem-phys.net/5/2901/2005/.

Beer, R.: TES on the Aura Mission: Scientific Objectives, Measurements, and Analysis Overview, IEEE T. Geosci. Remote, 44, 1102-1105, 2006.

Bernath, P. F., McElroy, C. T., Abrams, M. C., Boone, C. D., Butler, M., Camy-Peyret, C., Carleer, M., Clerbaux, C., Coheur, P. F., Colin, R., DeCola, P., Bernath, P. F., McElroy, C. T., Abrams, M. C., Boone, C. D., Butler, M., Camy-Peyret, C., Carleer, M., 
Clerbaux, C., Coheur, P. F., Colin, R., DeCola, P., DeMaziere, M., Drummond, J. R., Dufour, D., Evans, W. F. J., Fast, H., Fussen, D., Gilbert, K., Jennings, D. E., Llewellyn, E. J., Lowe, R. P., Mahieu, E., McConnell, J. C., McHugh, M., McLeod, S. D., Michaud, R., Midwinter, C., Nassar, R., Nichitiu, F., Nowlan, C., Rinsland, C. P., Rochon, Y. J., Rowlands, N., Semeniuk, K., Simon, P., Skelton, R., Sloan, J. J., Soucy, M. A., Strong, K., Tremblay, P., Turnbull, D., Walker, K. A., Walkty, I., Wardle, D. A., Wehrle, V., Zander, R., and Zou, J.: Atmospheric Chemistry Experiment (ACE): Mission overview, Geophys. Res. Lett., 32, L15S01, doi:10.1029/2005GL022386, 2005.

Bey, I., Jacob, D. J., Logan, J. A., and Yantosca, R. M.: Asian chemical outflow to the Pacific in spring: Origins, pathways, and budgets, J. Geophys. Res., 106, 23097-23113, 2001.

Brasseur, G. and Solomon, S.: Aeronomy of the middle atmosphere: Chemistry and physics of the stratosphere and mesosphere, 3. Edition, Springer, Dordrecht, The Netherlands, 2005.

Bregman, A., van Velthoven, P. F. J., Wienhold, F. G., Fischer, H., Zenker, T., Waibel, A., Frenzel, A., Arnold, F., Harris, G. W., Bolder, M. J. A., and Lelieveld, J.: Aircraft measurements of $\mathrm{O}_{3}$, $\mathrm{HNO}_{3}$, and $\mathrm{N}_{2} \mathrm{O}$ in the winter Arctic lower stratosphere during the Stratosphere-Troposphere Experiment by Aircraft Measurements (STREAM) 1, J. Geophys. Res., 100, 11245-11260, 1995.

Boone, C. D., Nassar, R., Walker, K. A., Rochon, Y., McLeod, S. D., Rinsland, C. P., and Bernath, P. F.: Retrievals for the atmospheric chemistry experiment Fourier-transform spectrometer, Appl. Optics, 44, 7218-7231, 2005.

Boynard, A., Clerbaux, C., Coheur, P.-F., Hurtmans, D., Turquety, S., George, M., Hadji-Lazaro, J., Keim, C., and Meyer-Arnek, J.: Measurements of total and tropospheric ozone from IASI: comparison with correlative satellite, ground-based and ozonesonde observations, Atmos. Chem. Phys., 9, 6255-6271, 2009,

http://www.atmos-chem-phys.net/9/6255/2009/.

Clerbaux, C., Hadji-Lazaro, J., Turquety, S., George, M., Coheur, P. F., Hurtmans, D., Wespes, C., Herbin, H., Blumstein, D., Tournier, B., and Phulpin, T.: The IASI/MetOp I mission: First observations and highlights of its Potential Contribution to GMES, COSPAR inf. Bul., vol. 2007, 19-24, 2007.

Clerbaux, C., Boynard, A., Clarisse, L., George, M., Hadji-Lazaro, J., Herbin, H., Hurtmans, D., Pommier, M., Razavi, A., Turquety, S., Wespes, C., and Coheur, P.-F.: Monitoring of atmospheric composition using the thermal infrared IASI/MetOp sounder, Atmos. Chem. Phys., 9, 6041-6054, 2009,

http://www.atmos-chem-phys.net/9/6041/2009/.

Clarisse, L., Coheur, P. F., Prata, A. J., Hurtmans, D., Razavi, A., Phulpin, T., Hadji-Lazaro, J., and Clerbaux, C.: Tracking and quantifying volcanic SO2 with IASI, the September 2007 eruption at Jebel at Tair, Atmos. Chem. Phys., 8, 7723-7734, 2008, http://www.atmos-chem-phys.net/8/7723/2008/.

Coheur, P. F., Barret, B., Turquety, S., Hurtmans, D., Hadji-Lazaro, J., and Clerbaux, C.: Retrieval and characterization of ozone vertical profiles from a thermal infrared nadir sounder, J. Geophys. Res., 110, D24303, doi:24310.21029/22005JD005845, 2005.

Coheur, P.-F., Clarisse, L., Turquety, S., Hurtmans, D., and Clerbaux, C.: IASI measurements of reactive trace species in biomass burning plumes, Atmos. Chem. Phys., 9, 5655-5667, 2009, http://www.atmos-chem-phys.net/9/5655/2009/.

Emmons, L. K., Hauglustaine, D. A., Müller, J. F., Carroll, M. A., Brasseur, G. P., Brunner, D., Staehelin, J., Thouret, V., and
Marenco, A.: Data composites of airborne observations of tropospheric ozone and its precursors, J. Geophys. Res., 105, 2049720538, 2000.

Fischer, H., Birk, M., Blom, C., Carli, B., Carlotti, M., von Clarmann, T., Delbouille, L., Dudhia, A., Ehhalt, D., Endemann, M., Flaud, J. M., Gessner, R., Kleinert, A., Koopman, R., Langen, J., Lpez-Puertas, M., Mosner, P., Nett, H., Oelhaf, H., Perron, G., Remedios, J., Ridolfi, M., Stiller, G., and Zander, R.: MIPAS: an instrument for atmospheric and climate research, Atmos. Chem. Phys., 8, 2151-2188, 2008,

http://www.atmos-chem-phys.net/8/2151/2008/.

Froidevaux, L., Livesey, N. J., Read, W. G., Jiang, Y. B., Jimenez, C. J., Filipiak, M. J., Schwartz, M. J., Santee, M. L., Pumphrey, H. C., Jiang, J. H., Wu, D. L., Manney, G. L., Drouin, B. J., Waters, J. W., Fetzer, E. J., Bernath, P. F., Boone, C. D., Walker, K. A., Jucks, K. W., Toon, G. C., Margitan, J. J., Sen, B., Webster, C. R., Christensen, L. E., Elkins, J. W., Atlas, E., Lueb, R. A., and Hendershot, R.: Early validation analyses of atmospheric profiles from EOS MLS on the Aura satellite, IEEE T. Geosci. Remote, 44(5), 1106-1121, 2006.

George, M., Clerbaux, C., Hurtmans, D., Turquety, S., Coheur, P.F., Pommier, M., Hadji-Lazaro, J., Edwards, D. P., Worden, H., Luo, M., Rinsland, C., and McMillan, W.: Carbon monoxide distributions from the IASI/METOP mission: evaluation with other space-borne remote sensors, Atmos. Chem. Phys. Discuss., 9, 9793-9822, 2009,

http://www.atmos-chem-phys-discuss.net/9/9793/2009/.

Hauglustaine, D. A., Brasseur, G. P., Walters, S., Rasch, P. J., Müller, J.-F., Emmons, L. K., and Carroll, M. A.: MOZART, a global chemical transport model for ozone and related chemical tracers, J. Geophys. Res., 103, 28291-28335, 1998.

Hauglustaine, D. A., Hourdin, F., Jourdain, L., Filiberti, M. A., Walters, S., Lamarque, J. F., and Holland, E. A.: Interactive chemistry in the laboratoire de meteorologie dynamique general circulation model: Description and background tropospheric chemistry evaluation, J. Geophys. Res.-Atmos., 109, D04314, doi:10.1029/2003JD003957, 2004.

Hudman, R. C., Jacob, D. J., Cooper, O. R., Evans, M. J., Heald, C. L., Park, R. J., Fehsenfeld, F., Flocke, F., Holloway, J., Hübler, G., Kita, K., Koike, M., Kondo, Y., Neuman, A., Oltmans S., Parrish, D., Robert, J. M., and Ryerson, T.: Ozone production in transpacific Asian pollution plumes and implications for ozone air quality in California, J. Geophys. Res., 109, D23S10, doi:10.1029/2004JD004974, 2004.

Irie, H., Kondo, Y., Koike, M., Danilin, M. Y., Camy-Peyret, C., Payan, S., Pommereau, J. P., Goutail, F., Renard, J.-B., Oelhaf, H., Wetzel, G., Toon, G. C., Sen, B., Blavier, J.-F., Salawitch, R., Bevilacqua, R. M., Russell J. M., Kanzawa, H., Nakajima, H., Yokota, Y., Sugita, T., and Sasano, Y.: Validation of $\mathrm{NO}_{2}$ and $\mathrm{HNO}_{3}$ measurements from the Improved Limb Atmospheric Spectrometer (ILAS) with the version 5.20 retrieval algorithm, J. Geophys. Res., 107, D248206, doi:10.1029/2001JD001304, 2002.

Irie, H., Sugita, T., Nakajima, H., Yokota, T., Oelhaf, H., Wetzel, G., Toon, G. C., Sen, B., Santee, M. L., Terao, Y., Saitoh, N., Ejiri, M. K., Tanaka, T., Kondo, Y., Kanzawa, H., Kobayashi, H., and Sasano, Y.: Validation of stratospheric nitric acid profiles observed by Improved Limb Atmospheric Spectrometer (ILASII), J. Geophys. Res., 111, D11S03, doi:10.1029/2005JD006115, 
2006.

Jin, J. J., Semeniuk, K., Manney, G. L., Jonsson, A. I., Beagley, S. R., McConnell, J. C., Rinsland, C. P., Boone, C. D., Walker, K. A., and Bernath, P. F.: Denitrification in the Arctic winter 2004/2005: Observation from ACE-FTS, Geophys. Res. Lett., 33, L19814, doi:10.1029/2006GL027687, 2006.

Koike, M., Kondo, Y., Irie, H., Murcray, F. J., Williams, J., Fogal, P., Blatherwick, R., Camy-Peyret, C., Payan, S., Oelhaf, H., Wetzel, G., Traub, W., Johnson D., Jucks K., Toon, G. C., Sen, B., Blavier, J.-F., Schlager, H., Ziereis, H., Toriyama, N., Danilin, M. Y., Rodriguez, J. M., Kanzawa, H., and Sasano Y.: A comparison of Arctic $\mathrm{HNO}_{3}$ profiles measured by the Improved Limb Atmospheric Spectrometer and balloon-borne sensors, J. Geophys. Res., 105, 6761-6771, 2000.

Massart, S., Clerbaux, C., Cariolle, D., Piacentini, A., Turquety, S., and Hadji-Lazaro, J.: First steps towards the assimilation of IASI ozone data into the MOCAGE-PALM system, Atmos. Chem. Phys., 9, 5073-5091, 2009,

http://www.atmos-chem-phys.net/9/5073/2009/.

Martin, R. V., Sauvage, B., Folkins, I., Sioris, C. E., Boone, C., Bernath, P., and Ziemke, J.: Space-based constraints on the production of nitric oxide by lightning, J. Geophys. Res., 112, D09309, doi:10.1029/2006JD007831, 2006.

Miyazaki, Y., Koike, Y., Fuelberg, H. E., Kiley, C. M., Kita, K., Takegawa, N., Sachse, G. W., Flocke, F., Weinheimer, A. J., Singh, H. B., Eisele, F. L., Zondlo, M., Talbot, R. W, Sandholm, S. T., Avery, M. A., and Blake, D. R.: Synoptic-scale transport of reactive nitrogen over the western Pacific in spring, J. Geophys. Res., 108, D208788, doi:10.1029/2002JD003248, 2003.

Neuman, J. A., Gao, R. S., Fahey, D. W., Holecek, J. C., Ridley, B. A., Walega, J. G., Grahek, F. E., Richard, E. C., McElroy, C. T., Thompson, T. L., Elkins, J. W., Moore, F. L., and Ray, E. A.: In situ measurements of $\mathrm{HNO}_{3}, \mathrm{NO}_{\mathrm{y}}, \mathrm{NO}$, and $\mathrm{O}_{3}$ in the lower stratosphere and upper troposphere, Atmos. Environ., 35, 5789-5797, 2001.

Neuman, J. A., Parrish, D. D., Trainer, M., Ryerson, T. B., Holloway, J. S., Nowak, J. B., Swanson, A., Flocke, F., Roberts, J. M., Brown, S. S., Stark, H., Sommariva, R., Stohl, A., Peltier, R., Weber, R., Wollny, A. G., Sueper, D. T., Hubler, G., and Fehsenfeld, F. C.: Reactive nitrogen transport and photochemistry in urban plumes over the North Atlantic Ocean, J. Geophys. Res., 111, D23S54, doi:10.1029/2005JD007010, 2006.

Orsolini, Y. J., Urban, J., and Murtagh, D. P.: Nitric acid in the stratosphere based on Odin observations from 2001 to 2007 Part 2: High-altitude polar enhancements, Atmos. Chem. Phys. Discuss., 8, 9591-9605, 2008, http://www.atmos-chem-phys-discuss.net/8/9591/2008/.

Razavi, A., Clerbaux, C., Wespes, C., Clarisse, L., Hurtmans, D., Payan, S., Camy-Peyret, C., and Coheur, P. F.: Characterization of methane retrievals from the IASI space-borne sounder, Atmos. Chem. Phys. Discuss., 9, 7615-7643, 2009,

http://www.atmos-chem-phys-discuss.net/9/7615/2009/.

Rinsland, C. P., Zander, R., and Demoulin, P., Ground-based infrared measurements of $\mathrm{HNO}_{3}$ total column abundances: Longterm trend and variability, J. Geophys. Res., 96, 9379-9389, 1991.

Rodgers, C. D.: Inverse methods for atmospheric sounding: Theory and Practice, World Sci., River Edge, NJ, USA, 2000.

Rothman, L. S., Jacquemart, D., Barbe, A., Chris Benner, D., Birk,
M., Brown, L. R., Carleer, M. R., Chackerian Jr., C., Chance, K., Coudert, L. H., Dana, V., Devi, V. M., Flaud, J.-M., Gamache, R. R., Goldman, A., Hartmann, J.-M., Jucks, K. W., Maki, A. G., Mandin, J.-Y, Massie, S. T., Orphal, J., Perrin, A., Rinsland, C. P., Smith, M. A. H., Tennyson, J., Tolchenov, R. N., Toth, R. A., Vander Auwera, J., Varanasi, P., and Wagner, G.: The HITRAN 2004 molecular spectroscopic database, J. Quant. Spectrosc. Ra., 96, 139-204, 2005.

Santee, M. L., Manney, G. L., Froidevaux, L., Read, W. G., and Waters, J. W.: Six years of UARS Microwave Limb Sounder $\mathrm{HNO}_{3}$ observations: Seasonal, interhemispheric, and interannual variations in the lower stratosphere, J. Geophys. Res., 104, 82258246, 1999.

Santee, M. L., Manney, G. L., Livesey, N. J., and Read, W. G.: Three-dimensional structure and evolution of stratospheric $\mathrm{HNO}_{3}$ based on UARS Microwave Limb Sounder measurements, J. Geophys. Res., 109, D15306, doi:10.1029/2004JD004578, 2004.

Santee, M. L., Manney, G. L., Livesey, N. J., Froidevaux, L., Pumphrey, H. C., Read, W. G., Schwartz, M. J., and Waters, J. W.: Polar processing and development of the 2004 Antarctic ozone hole: First results from Aura MLS, J. Geophys. Res., 32, L12817, doi:10.1029/2005GL022582, 2005.

Santee, M. L., Lambert, A., Read, W. G., Livesey, N. J., Cofield, R. E., Cuddy, D. T., Daffer, W. H., Drouin, B. J., Froidevaux, L., Fuller, R. A., Jarnot, R. F., Knosp, B. W., Manney, G. L., Perun, V. S., Snyder, W. V., Stek, P. C., Thurstans, R. P., Wagner, P. A., Waters, J. W., Muscari, G., de Zafra, R. L., Dibb, J. E., Fahey, D. W., Popp, P. J., Marcy, T. P., Jucks, K. W., Toon, G. C., Stachnik, R. A., Bernath, P. F., Boone, C. D., Walker, K. A., Urban, J., and Murtagh, D.: Validation of the Aura Microwave Limb Sounder $\mathrm{HNO}_{3}$ Measurements, J. Geophys. Res., 112, D24S40, doi:10.1029/2007JD008721, 2007.

Schlüssel, P., Hultberg, T. H., Philipps, P. L., August, T., and Calbet, X.: The operational IASI Level 2 processor, Adv. Space Res., 36, 982-988, doi:10.1016/j.asr.2005.03.008, 2005.

Schneider, J., Arnold, F., Curtius, J., Sierau, B., Fischer, H., Hoor, P., Wienhold, F. G., Parchatka, U., Zhang, Y. C., Schlager, H., Ziereis, H., Feigl, Ch., Lelieveld, J., Scheeren, H. A., and Bujok, O.: The temporal evolution of the ratio $\mathrm{HNO}_{3} / \mathrm{NO}_{\mathrm{y}}$ in the Arctic lower stratosphere from January to March 1997, Geophys. Res. Lett, 26(8), 1125-1128., 1999.

Stiller, G. P., Tsidu, G. M., von Clarmann, T., Glatthor, N., Höpfner, M., Kellmann, S., Linden, A., Ruhnke, R., and Fischer, H.: An enhanced $\mathrm{HNO}_{3}$ second maximum in the Antarctic midwinter upper stratosphere 2003, J. Geophys. Res., 110, D20303, doi:10.1029/2005JD006011, 2005.

Solomon, S.: Stratospheric Ozone Depletion: A review of concepts and history, Rev. Geophys., 37, 275-316, 1999.

Talbot, R. W., Dibb, J. E., Scheuer, E. M., Kondo, Y., Koike, M., Singh, H. B., Salas, L. B., Fukui, Y., Ballenthin, J. O., Meads, R. F., Miller, T. M., Hunton, D. E., Viggiano, A. A, Blake, D. R., Blake, N. J., Atlas, E., Flocke, F., Jacob, D. J., and Jeagle, L.: Reactive Nitrogen Budget During the NASA SONEX Mission, Geophys. Res. Lett., 26(20), 3057-3060, 1997.

Trainer, M., Parrish, D. D., Buhr, M. P., Norton, R. B., Fehsenfeld, F. C., Anlauf, K. G., Bottenheim, J. W., Tang, Y. Z., Wiebe, H. A., Roberts, J. M., Tanner, R. L., Newman, L., Bowersox, V. C., Meagher, J. F., Olszyna, K. J., Rodgers, M. O., Wang, T., 
Berresheim, H., Demerjian, K. L., and Roychowdhury, U. K.: Correlation of ozone with $\mathrm{NO}_{\mathrm{y}}$ in photochemically aged air, J. Geophys. Res., 98, 2917-2925, 1993.

Tsidu, G. M., Stiller, G. P., von Clarmann, T., Funke, B., Hopfner, M., Fischer, H., Glatthor, N., Grabowski, U., Kellmann, S., Kiefer, M., Linden, A., Lopez-Puertas, M., Milz, M., Steck, T., and Wang, D. Y.: $\mathrm{NO}_{\mathrm{y}}$ from Michelson Interferometer for Passive Atmospheric Sounding on Environmental Satellite during the Southern Hemisphere polar vortex split in September/October 2002, J. Geophys. Res., 110, D11301, doi:10.1029/2004JD005322, 2005.

Turquety, S., Hadji-Lazaro, J., Clerbaux, C., Hauglustaine, D. A., Clough, S. A., Casse, V., Schlüssel, P., and Mégie, G.: Operational trace gas retrieval algorithm for the Infrared Atmospheric Sounding Interferometer, J. Geophys. Res., 109, D21301, doi:21310.21029/22004JD00482, 2004.

Turquety, S., Hurtmans, D., Hadji-Lazaro, J., Coheur, P.-F., Clerbaux, C., Josset, D., and Tsamalis, C.: Tracking the emission and transport of pollution from wildfires using the IASI CO retrievals: analysis of the summer 2007 Greek fires, Atmos. Chem. Phys., 9, 4897-4913, 2009, http://www.atmos-chem-phys.net/9/4897/2009/.

Urban, J., Lautie, N., Le Flochmoën, E., Jimenez, C., Eriksson, P., de La Noe, J., Dupuy, E., Ekstrom, M., Amraoui, L. E., Frisk, U., Murtagh, D., Olberg, M., and Ricaud, P.: Odin/SMR limb observations of stratospheric trace gases: Level 2 processing of $\mathrm{ClO}, \mathrm{N}_{2} \mathrm{O}, \mathrm{HNO}_{3}$, and $\mathrm{O}_{3}$, J. Geophys. Res., 110, D14307, doi:10.1029/2004JD005741, 2005.

Urban, J., Pommier, M., Murtagh, D. P., Santee, M. L., and Orsolini, Y. J.: Nitric acid in the stratosphere based on Odin observations from 2001 to 2007 - Part 1: A global climatology, Atmos. Chem. Phys. Discuss., 8, 9569-9590, 2008,

http://www.atmos-chem-phys-discuss.net/8/9569/2008/.

Vigouroux, C., De Maziére, M., Errera, Q., Chabrillat, S., Mahieu, E., Duchatelet, P., Wood, S., Smale, D., Mikuteit, S., Blumenstock, T., Hase, F., and Jones, N.: Comparisons between groundbased FTIR and MIPAS N2O and HNO3 profiles before and after assimilation in BASCOE, Atmos. Chem. Phys., 7, 377-396, 2007, http://www.atmos-chem-phys.net/7/377/2007/. von Clarmann, T., Höpfner, M., Kellmann, S., Linden, A., Chauhan, S., Funke, B., Grabowski, U., Glatthor, N., Kiefer, M., Schieferdecker, T., Stiller, G. P., and Versick, S.: Retrieval of temperature, $\mathrm{H}_{2} \mathrm{O}, \mathrm{O}_{3}, \mathrm{HNO}_{3}, \mathrm{CH}_{4}, \mathrm{~N}_{2} \mathrm{O}, \mathrm{ClONO}_{2}$ and $\mathrm{ClO}$ from MIPAS reduced resolution nominal mode limb emission measurements, Atmos. Meas. Tech., 2, 159-175, 2009, http://www.atmos-meas-tech.net/2/159/2009/.

Wang, D. Y., Höpfner, M., Blom, C. E., Ward, W. E., Fischer, H., Blumenstock, T., Hase, F., Keim, C., Liu, G. Y., Mikuteit, S., Oelhaf, H., Wetzel, G., Cortesi, U., Mencaraglia, F., Bianchini, G., Redaelli, G., Pirre, M., Catoire, V., Huret, N., Vigouroux, C., De Maziére, M., Mahieu, E., Demoulin, P., Wood, S., Smale, D., Jones, N., Nakajima, H., Sugita, T., Urban, J., Murtagh, D., Boone, C. D., Bernath, P. F., Walker, K. A., Kuttippurath, J., Kleinböhl, A., Toon, G., and Piccolo, C.: Validation of MIPAS $\mathrm{HNO}_{3}$ operational data, Atmos. Chem. Phys., 7, 4905-4934, 2007, http://www.atmos-chem-phys.net/7/4905/2007/.

Wespes, C., Hurtmans, D., Herbin, H., Barret, B., Turquety, S., Hadji-Lazaro, J., Clerbaux, C., and Coheur, P. F.: First global distributions of nitric acid in the troposphere and the stratosphere derived from infrared satellite measurements, J. Geophys. Res. 112, D13311, doi:10.1029/2006JD008202, 2007.

Wolff, M. A., Kerzenmacher, T., Strong, K., Walker, K. A., Toohey, M., Dupuy, E., Bernath, P. F., Boone, C. D., Brohede, S., Catoire, V., von Clarmann, T., Coffey, M., Daffer, W. H., De Maziére, M., Duchatelet, P., Glatthor, N., Griffith, D. W. T., Hannigan, J., Hase, F., Höpfner, M., Huret, N., Jones, N., Jucks, K., Kagawa, A., Kasai, Y., Kramer, I., Küllmann, H., Kuttippurath, J., Mahieu, E., Manney, G., McLinden, C., Mébarki, Y., Mikuteit, S., Murtagh, D., Piccolo, C., Raspollini, P., Ridolfi, M., Ruhnke, R., Santee, M., Senten, C., Smale, D., Tétard, C., Urban, J., and Wood, S.: Validation of $\mathrm{HNO}_{3}, \mathrm{ClONO}_{2}$, and $\mathrm{N}_{2} \mathrm{O}_{5}$ from the Atmospheric Chemistry Experiment Fourier Transform Spectrometer (ACE-FTS), Atmos. Chem. Phys. Discuss., 8, 2429-2512, 2008, http://www.atmos-chem-phys-discuss.net/8/2429/2008/. 